\title{
PENDIDIKAN MUSLIMAH BERCADAR DI PESANTREN BER-MANHAJ SALAFI DI KOTA METRO
}

\author{
Wahyudin \\ Khotijah \\ Dharma Setyawan
}

Institut Agama Islam Negeri (IAIN) Metro

JL. Ki Hajar Dewantara No.15A, Iringmulyo, Metro Timur, Kota Metro, Lampung

Email: ywah996@gmail.com, khotijahawa34@gmail.com dan dharmasetyawan405@gmail.com

\begin{tabular}{|c|c|c|}
\hline Diterima: & Revisi: & Disetujui: \\
23 Agustus 2018 & 15 Oktober 2018 & 11 November 2018 \\
\hline
\end{tabular}

\begin{abstract}
The rapid development of the salafi movement in Indonesia is inseparable from their main approach, namely, purification and education. In the realm of education, there is a phenomenon of the emergence of various salafi schools in various regions in Indonesia, including in the city of Metro, Lampung. Two topics related to the Islamic education system in salafi pesantren and the position of women in salafi pesantren were the questions this research was based on. This research was a qualitative-descriptive study. Data collection was done by direct observation, documentation, and in-depth interviews. The results of the study showed that in terms of the teaching method, the salafi pesantrens in Metro city were not too different from the learning systems in other Islamic boarding schools. Meanwhile, for salafi women, Islamic boarding schools provide a special program for women they call tarbiyah al-nisa'.
\end{abstract}

Keyword: women, salafi, Islamic education, pesantren, and cadar

\begin{abstract}
Abstrak
Pesatnya perkembangan gerakan salafi di Indonesia tidak terlepas dari pendekatan utama mereka yakni, pemurnian agama (purification) dan pendidikan (education). Dalam ranah pendidikan, terdapat fenomena munculnya berbagai pesantren bermanhaj salafi di berbagai daerah di Indonesia, termasuk di kota Metro, Lampung. Dua pertanyaan, yakni (1) bagaimana sistem pendidikan Islam di pesantren bermanhaj salafi dan (2) bagaimana posisi perempuan di pesantren bermanhaj salafi mendasari riset ini. Penelitian ini merupakan sebuah penelitian qualitatif-deskriptif. Pengumpulan data dilakukan dengan observasi langsung, dokumentasi, dan wawancara mendalam (in-depth interview). Hasil penelitian menunjukkan
\end{abstract}


bahwa dalam sisi metode pengajaran, pesantren salafi di kota Metro tidak terlalu berbeda dengan sistem pembelajaran di pesantren bermanhaj lain. Sementara itu, untuk perempuan salafi, pesantren menyediakan sebuah program khusus wanita yang mereka sebut sebagai tarbiyah al-nisa'.

Kata Kunci: perempuan, salafi, pendidikan Islam, pesantren, dan cadar

\section{A. Pendahuluan}

Gerakan Salafi adalah gerakan puritan yang mengambil inspirasi utamanya dari gaya Islam Saudi. ${ }^{1}$ Kata "salafi" diasosiasikan dengan al-salaf al-shalih yang bermakna 'orang terdahulu yang saleh', yakni para vulama klasik yang menjadikan al-Qur`an dan Hadits sebagai sumber ajaran Islam. ${ }^{2}$ Salafi merupakan gerakan Islam yang murni dan bebas dari penambahan, pengurangan dan perubahan. Salafiyah adalah al-Quran dan sunnah. Gerakan ini mengklaim bahwa mereka bukan partai politik atau madzhab yang baru. Gerakan ini meyakini bahwa dakwah mereka lah yang merupakan Islam dalam totalitasnya, yang menuntun manusia apapun budayanya, ras atau warna kulitnya.3 Wiktorowicz menge-mukakan bahwa "All Salafis share a puritanical approach to the religion intended to eschew religious innovation by strictly replicating the model of the Prophet Muhammad".4 Menurutnya, semua gerakan salafi menerapkan

1 Eva F Nisa, "Embodied Faith: Agency and Obedience among Face-veiled University Students in Indonesia", The Asia Pacific Journal of Anthropology, vol. 13, No. 4, August 2012, h. 366-381

2 Thomas Hegghammer, "Jihadi Salafis or Revolutionaries: On Religion and Politics in the Study of Islamist Militancy", dalam R Meijer (ed), Global Salafism: Islam's New Religious Movement, (London/New York: Hurst/Columbia University Press, 2009), h. 247.

3 M. Imdadun Rahmat, Arus Baru Islam Radikal, Transmisi Revitalisme Islam Timur Tengah di Indonesia, (Jakarta: PT. Erlangga, 2005), h. 61

${ }^{4}$ Quintan Wiktorowicz. "Anatomy of the Salafi Movement", Studies in Conflict \& Terrorism, 29:3, 2006. h. 207-239, DOI: 10.1080/10576100500497004. Diuraikan oleh Wiktorowicz bahwa, para penentang Salafisme sering membubuhkan kata "Wahhabi" untuk menunjukkan pengaruh asing dari Salafi ini. Ini dimaksudkan untuk menandakan pengikut Abd al-Wahhab dan paling sering digunakan di negara-negara di mana Salafi adalah minoritas kecil dari komunitas Muslim tetapi telah membuat erobosan baru-baru ini dalam "mengubah" populasi lokal ke ideologi gerakan. Di 
pendekatan puritan terhadap agama yang dimaksudkan untuk menghindari inovasi agama (bid'ah) dengan secara ketat meniru model Nabi Muhammad.

Untuk dapat lebih memahami salifisme, kita dapat fokus pada tiga tema utama yang menentukan pendekatan salafi agama: kemurnian dalam sumber-sumber agama (purity in the sources of the religion), kemurnian dalam praktik (purity in practice), dan kemurnian dalam teologi (purity in theology). Salafi percaya bahwa umat Islam hanya harus mengikuti sumber-sumber kitab suci agama. Mereka seharusnya hanya mengikuti Al-Qur'an dan ajaran asli Nabi. Gerakan salafi cenderung menolak kreasi institusional yang baru, atau perkembangan-perkembangan terbaru dalam Islam. Misalnya, mereka akan menolak nasionalisme. Mereka menolak banyak pusat otoritas yang telah berkembang di dunia Islam selama 1.400 tahun terakhir, karena ini pada awalnya bukan bagian dari agama Islam. Ini awalnya tidak termasuk dalam ajaran Nabi. ${ }^{5}$ Gerakan ini berasal dari Mesir pada akhir abad ke-19 dan didukung oleh tiga pelopor reformisme Islam, Jamal al-Din al Afghani, Muhammad 'Abduh dan Rashid Ridla. ${ }^{6}$ Di Indonesia, tumbuh kembang gerakan Salafi tidak hanya berjalan sendirinya tanpa bantuan dari pihak lain. Din Wahid menguraikan

negara-negara ini, otoritas lokal keagamaan telah menanggapi meningkatnya pengaruh pemikiran Salafi dengan menggambarkan Salafi sebagai Wahhabi, sebuah istilah yang bagi sebagian besar non-Salafi memunculkan gambar Arab Saudi. Itu sifat asing "Wahhabi" disandingkan dengan bentuk-bentuk asli Islam asli. Dengan cara ini, penentang Salafisme menyuntikkan nasionalisme ke dalam wacana agama dengan mengangkat pengaruh asing. Namun, gerakan Salafi sendiri tidak pernah menggunakan istilah ini. Bahkan satu akan sulit sekali menemukan individu yang menyebut diri mereka sebagai Wahhabi atau organisasi yang menggunakan "Wahhabi" dalam judul mereka atau merujuk ke ideologi mereka dengan cara ini (kecuali mereka berbicara untuk audiens Barat yang tidak terbiasa dengan terminologi Islam, dan bahkan penggunaannya pun demikian terbatas dan sering muncul sebagai "Salafi/Wahhabi").

5 D Byman. (2014). Variations within the Salafi Movement: Three Main Themes in Salafism. Diakses dari https://repository.library.georgetown.edu/ bitstream/handle/10822/1041681/GUIX-501-01-14-W4-S12.pdf?sequence=1 pada 2 November 2018.

6 W. Ende, "Salafiyya", Encyclopedia of Islam, Vol. 8 (Leiden: Brill, 1995), h. 900. 
bahwa terdapat dukungan pendanaan yang kuat dari tiga sumber, yakni sumber internasional, sumbangan yayasan, dan sumbangan individu. Sumber internasional itu misalnya, Kuwaiti Charitable Foundation, Jamiyyat Ihya' al Turast al Islam, dan The Qatari Sheikh Eid Charity Foundation. ${ }^{7}$

Terkait bagaimana asal mula pendidikan Salafi masuk ke Indonesia, Amanda Kovacs menguraikan bahwa Arab Saudi merupakan penyedia utama pendidikan Salafi di Indonesia. Namun menurutnya, banyak yang menilai bahwasanya selain mempromosikan salafisme, materi pendidikan Saudi menyajikan materi ajar yang cenderung mendiskreditkan pemahaman agama dari komunitas agama lain yang sudah terlebih dahulu berdiri di Indonesia. Program pendidikan Saudi bertujuan untuk menciptakan aliansi global dan melegitimasi klaim Saudi sebagai pemimpin Islam-di dalam dan luar negeri. ${ }^{8}$

Pesatnya perkembangan gerakan salafi tentu saja tidak terlepas dari proses pendidikan Islam yang mereka laksanakan. Juga, karena masih banyaknya permasalahan di bidang pendidikan ${ }^{9}$ menjadikan format pendidikan mereka diterima oleh sebagian masyarakat karena banyak yang memandang pentingnya integrasi nilai-nilai keislaman ke dalam semua mata pelajaran. ${ }^{10}$ Sebagaimana kita ketahui, dalam perkembangannya, pendidikan Islam mengalami penyesuaian dengan keadaan jaman dengan pengelolaan/sistem

7 Din Wahid. "Nurturing The Salafy Manhaj: A Study of Salafi Pesantrens in Contemporary." Disertasi Utrecht University, 2014, h. 96-97.

${ }^{8}$ Amanda Kovacs. Saudi Arabia Exporting Salafi Education and Radicalizing Indonesia's Muslims. (GIGA Focus International Edition, 7). Hamburg: GIGA German Institute of Global and Area Studies-Leibniz-Institut für Globale und Regionale Studien. Diakses dari https://nbn-resolving.org/urn:nbn:de:0168-ssoar-402325 pada tanggal 20 November 2018.

${ }_{9}$ Nurul Afifah, "Problematika Pendidikan di Indonesia (Telaah dari Aspek pembelajaran)," Elementary: Jurnal Ilmiah Pendidikan Dasar, 1, No. 1 (2015): h. 43.

${ }^{10}$ Ahmad Madkur \& Azkia M. Albantani, "Instilling Islamic Values in Foreign Language Teaching: An Indonesian Context". The International Conference on Education in Muslim Society. (Advances in Social Science, Education and Humanities Research, volume 115, Atlantis Press, 2018), h. 97-103. 
modern sehingga lahirlah sistem madrasah. ${ }^{11}$ Pesantren dan madrasah di Indonesia mempunyai karakter asli yang berbeda dengan pendidikan Islam di dunia. Menurut Azra, dari awal mulanya hingga kini, pendidikan Islam di Indonesai selalu mengalami perkembangan dan pergeseran. ${ }^{12}$ Termasuk munculnya pesantren model manhaj salafi, yang mana pesantren ini berbeda karakternya dengan pesantren-pesantren salaf maupun yang kholaf. ${ }^{13}$ Terkait bagaimana asal mula pendidikan Salafi masuk ke Indonesia, Amanda Kovacs menguraikan bahwa Arab Saudi merupakan penyedia utama pendidikan Salafi di Indonesia. Namun menurutnya, banyak yang menilai selain mempromosikan Salafisme, materi pendidikan Saudi menyajikan mendiskreditkan pemahaman agama dari komunitas agama lain yang sudah terlebih dahulu berdiri di Indonesia. Program pendidikan Saudi bertujuan untuk menciptakan aliansi global dan melegitimasi klaim Saudi sebagai pemimpin Islam—di dalam dan luar negeri. ${ }^{14}$

Perkembangan pesantren manhaj salafi di Indonesia terbilang masif dan cepat pada tiga dekade akhir ini terlebih setelah tumbangnya rezim orde baru. Perkembangannya ini dapat kita lihat sebagai representasi dari dampak Islam arus global (gerakan salafis) yang tidak terlepas dari kontroversi dengan lingkungan warga di mana mereka berada. Kontroversi ini muncul dikarenakan gerakan tersebut termasuk, juga pesantren ber-manhaj salafi, bertumbuh dengan membawa corak sebagai pendidikan Islam yang eksklusif yang

11 Imam Solihin, "Madrasah dan Pertumbuhan Keilmuan Dunia Islam: Sebuah Kajian Sosio-Historis". Elementary: Jurnal Ilmiah Pendidikan Dasar, [S.I.], v. 4, n. 1, june 2018, h. 97-106.

12 Azyumardi Azra, Pendidikan Islam Tradisi Dan Modernisasi Di Tengah Tantangan Millenium III, (Jakarta: Kencana, 2012), h. 95.

13 Irham, "Pesantren Manhaj Salafi: Pendidikan Islam Model Baru di Indonesia" dalam Ulul Albab Vol. 17, No.1 Tahun 2016, h. 2.

${ }^{14}$ Amanda Kovacs, Saudi Arabia Exporting Salafi Education and Radicalizing Indonesia's Muslims, (GIGA Focus International Edition, 7). Hamburg: GIGA German Institute of Global and Area Studies-Leibniz-Institut für Globale und Regionale Studien. Diakses dari https://nbn-resolving.org/urn:nbn:de:0168-ssoar-402325 pada tanggal 20 November 2018. 
kurang akomodatif dengan budaya masyarakat. Tumbuhnya gerakan salafi dan pesantren ber-manhaj salafi misalnya, munculnya Dewan Dakwah Islam Indonesia, Lembaga Ilmu Pengetahuan Islam dan Bahasa Arab (LIPIA), gerakan aktivis Islam kampus, berdirinya pesantren al-Irsyad Tangerang, dan lain sebagainya, yang sering berseberangan pandangan dan budaya dengan masyarakat. Munculnya gerakan tersebut berupaya mengembangkan ideologi manhaj salafi yang kurang akomodatif dengan kondisi sosiokultur/sosio-historis masyarakat sehingga gerakan salafi ini kerap menimbulkan konflik masyarakat. ${ }^{15}$

Melihat pesantren memiliki tingkat keterterimaan yang cukup tinggi di masyarakat, gerakan salafi kemudian secara luas mendirikan pesantren-pesantren bermanhaj salafi. Menurut Stiawan dan Tohiri, terdapat dua format pendidikan pondok pesantren salafi di kota Magelang, diantaranya pondok pesantren An Nur dan pondok pesantren Sirojul Huda yang di dalamnya hanya mengajarkan materimateri keagamaan saja, dan pondok pesantren salafi yang di dalamnya menyelenggarakan program sekolah paket dan pembekalan life skill kepada santrinya, yaitu pondok pesantren Selamat. Hal tersebut sebagai langkah dan upaya pemenuhan harapan dari masyarakat dalam rangka pelayanan pendidikan yang seimbang antara ilmu agama sebagai landasan hidup, dengan ilmu pengetahuan umum sebagai pemenuhan kebutuhan hidup. ${ }^{16}$

Selain lembaga-lembaga formal yang telah mereka dirikan, kelompok Salafi juga aktif mengisi ceramah keagamaan, khutbah, tablig akbar, halaqah, dan daurah. Kegiatankegiatan tersebut didokumentasikan menjadi kaset, VCD, DVD, yang kemudian dijual bersama buku, jurnal, dan majalah. Di dalam bidang peneribitan, gerakan Salafi juga bergerak secara massif. Setiap tahun, peserta

\footnotetext{
15 Noorhaidi. "Laskar Jihad Islam, Militancy and The Quest for Identity in Post-New Order Indonesia.” Ph.D. Dissertation. Utrecht university. 2005.

16 Kelik Stiawan dan M. Tohirin, "Format Pendidikan Pondok Pesantren Salafi dalam Arus Perubahan Sosial di Kota Magelang", jurnal CAKRAWALA, Vol. X, No. 2, Desember 2015, h.194-209.
} 
Islamic Book Fair di Jakarta semakin bertambah. Hal ini menandakan bahwa pertumbuhan penerbit-penerbit Islam semakin berkembang. Tak terkecuali mereka yang ber-manhaj Salafi pun ikut andil dalam pesta buku Islam tahunan tersebut. Kita lihat pertambahannya, tahun 2004 diikuti 73 peserta, 2007 diikuti 167 peserta, dan tahun 2011 dihadiri 300 peserta. Sedangkan dalam survey IKAPI (Ikatan Penerbit Indonesia) tahun 2005 hampir sepertiga dari 10.000 buku yang ditebitkan setiap tahun adalah buku-buku Islam. Buku-buku Islam rata-rata dicetak 3000-5000 dan bahkan 10.000 eksemplar sekali cetak. Diantara buku yang terjual hingga 12.000 eksemplar yaitu Aku Melawan Teroris karya Imam Samudra. ${ }^{17}$

Di samping itu, untuk menyesuaikan dengan perkembangan zaman, mereka juga memberikan tausiah, nasehat, dan dakwah melalui media penyiaran, seperti stasiun televisi dan radio, serta dunia maya, seperti website, blog, mailing list (milis), dan jejaring sosial. ${ }^{18}$

Di kalangan masyarakat umum, gerakan Salafi seringkali dikenal sebagai kelompok yang para perempuannya mengenakan tidak hanya jilbab atau kerudung besar tetapi juga cadar atau niqab. Para perempuan Salafi ini juga dikenal cukup ekslusif dan kurang berbaur dengan anggota masyarakat lain. Hal ini membuat beberapa pihak melihat bahwa perempuan Salafi tidak memiliki peran yang sama besarnya dengan kaum pria, seperti yang diterapkan oleh organisasi keagamaan yang lain di Indonesia seperti Nahdlatul Ulama dengan Muslimatnya ${ }^{19}$ dan Muhammadiyah dengan Aisyiayahnya ${ }^{20}$.

17 International Crisis Group, "Indonesia: Industri Penerbitan Jemaah Islamiyah", Asia Report, No. 142, 24 Pebruari 2008, hal. 2.

18 Prima, A., R., M “Mediatisasi pada Aktivitas Dakwah Perempuan Salafi” RI'AYAH, Vol. 01, No. 02 Juli-Desember 2016

${ }^{19}$ Sejarah pergerakan wanita NU memiliki akar kesejarahan panjang dengan pergumulan yang amat sengit yang akhirnya memunculkan berbagai gerakan wanita baik Muslimat, fatayat hingga Ikatan pelajar putri NU. Sejarah mencatat bahwa kongres NU di Menes tahun 1938 itu merupakan forum yang memiliki arti tersendiri bagi proses katalisis terbentuknya organisasi Muslimat NU. Sejak kelahirannya pada tahun 1926, NU adalah organisasi yang anggotanya hanyalah kaum laki-laki belaka. Dalam kongres itu, untuk pertama kalinya tampil seorang muslimat $\mathrm{NU}$ di atas 
Berbeda dari para perempuan di dalam kedua organisasi besar tersebut dan organisasi keagamaan Islam lain pada umumnya, para perempuan Salafi cenderung lebih tertutup dan lebih dimaksimalkan kiprahnya di dalam ranah domestik (rumah tangga) mereka. Berdasarkan uraian diatas, penulis tertarik untuk mengehatui bagaimana sistem pengajaran lembaga pendidikan ber-manhaj salafi di Kota Metro, dalam hal ini Ma'had Ittibaus Salaf. Juga, melalui penelitian ini, penulis ingin mengetahui bagaimana posisi wanita salafi di dalam proses pendidikan Islam di kelompok ini.

\section{B. Temuan dan Pembahasan}

\section{Tipe Manhaj Salafi di Kota Metro}

Gerakan salafi di kota Metro tergolong kepada tipe salafi puris yang juga merupakan tipe salafi yang paling banyak di Indonesia. Sebagaimana dijelaskan oleh Din Wahid bahwa gerakan salafi di Indonesia dapat diklasifikasikan menjadi tiga jenis, yaitu salafi puris, salafi haraki, dan salafi jihadi. Pada umumnya, ketiga kelompok salafi ini dapat dibedakan dari sikap mereka terhadap penerimaan atau penolakan kebijakan pemerintah. ${ }^{21}$ Selanjutnya informan penelitian ini juga menyatakan bahwa dalam ajaran salafi ia sebagai salah satu jamaahnya selalu didorong untuk

podium, berbicara tentang perlunya wanita NU mendapatkan hak yang sama dengan kaum lelaki dalam menerima didikan agama melalui organisasi NU.

20 Aisyiyah sebagai salah satu organisasi otonom bagi Wanita Muhammadiyah yang didirikan di Yogyakarta pada 27 Rajab 1335 H bertepatan dengan 19 Mei 1917 oleh Nyai Ahmad Dahlan. 'Aisyiyah adalah sebuah gerakan perempuan Muhammadiyah yang lahir hampir bersamaan dengan lahirnya organisasi Islam terbesar di Indonesia ini. Dalam kiprahnya hampir satu abad di Indonesia, saat ini 'Aisyiyah telah memiliki 33 Pimpinan Wilayah "Aisyiyah (setingkat Propinsi), 370 Pimpinan Daerah 'Aisyiyah (setingkat kabupaten), 2332 Pimpinan Cabang 'Aisyiyah (setingkat Kecamatan) dan 6924 Pimpinan Ranting 'Aisyiyah (setingkat Kelurahan). Selain itu, 'Aisyiyah juga memiliki amal usaha yang bergerak diberbagai bidang yaitu: pendidikan, kesehatan, kesejahteraan sosial, ekonomi dan pemberdayaan masyarakat. Amal Usaha dibidang pendidikan saat ini berjumlah 4560 yang terdiri dari Kelompok Bermain, Pendidikan Anak Usia Dini, Taman Kanak-Kanak, Tempat Penitipan Anak, Sekolah Dasar, Sekolah Menengah Pertama, dan lain-lain.

21 Din Wahid. "Nurturing The Salafy Manhaj: A Study of Salafi Pesantrens in Contemporary." Disertasi Utrecht University, 2014, h. 96-97. 
menyuarakan kembali pada al-Quran dan al Hadits. Selain itu, praktik-praktik keagamaan yang berbau syirik, bid'ah, khurafat, dan tahayul harus dijauhi.

"Kami selalu diajarkan bahwa semua ibadah yang kita lakukan harus bersumber dari Qur'an dan sunnah, jadi kita nggak boleh ikut-ikutan tradisi ibadah yang tidak ada dalilnya karena itu bid'ah"22 Tipe salafi puris ini memang lebih inklusif jika dibandingkan dengan jenis salafi haraki, yang selain menjalankan purifikasi ajaran, juga melakukan pergerakan pemikirandan, dan salafi jihadi yang dapat melancarkan pemberontakan atau penyerangan kepada kelompok yang menurut mereka salah. Sebagai contoh misalnya melakukan pemboman (radikalisme) dengan atas nama jihad menegakkan negara yang berdasar syariat agama, memerangi orang kafir, syirik dan seterusnya. Menurut Adis Duderija, pola pemahaman ajaran agama oleh kelompok salafi sangat tekstualis sehingga keberagamaan yang muncul cenderung menjadi fundamental. Ia menyebut kelompoak manhaj salafi ini dengan neo-traditional salafism. ${ }^{23}$ Jenis keberagamaan seperti itu juga ditemui oleh kelompok salafi di negara lain. Misalnya di Swedia, Susanne Olsson menemukan bahwa ideologi memurnikan Islam (purifikasi) selalu ditekankan. Orang-orang ini cenderung eksklusif dan cenderung menyalahkan orang lain yang tidak sesuai dengan prinsip kelompoknya walaupun sesama muslim. ${ }^{24}$

Gerakan salafi di Kota Metro, khususnya yang menjadi jama'ah ma'had Ittibaus Salaf, sebagaimana umumnya jamaah salafiyyun, memiliki pemahaman utama, yakni memegang teguh

22 Wawancara dengan IV, salah satu muslimah gerakan Salafi di kota Metro, pada tanggal 13 Agustus 2017.

23 Adis Duderija, "Constructing the Religious Self and the Other: NeoTraditional Salafi Manhaj." Islam and Christian-Muslim Relations, 21 (1), 2010, h. 7593.

${ }^{24}$ Susanne Olsson, "Swedish Puritan Salafism: A Hijra Within." Comparative Islamic Studies 8 (1-2), 2012, h. 71-92. http://www.equinoxpub.com/journals/index. php/CIS/article/viewArticle/20939 accessed 6/6/2015. 
nilai-nilai dari generasi salaf untuk dijadikan sebagai teladan (qudwah) bagi mereka. Keteladan yang diambil dari generasi salaf ini meliputi segala spek baik dalam hal manhaj (metode) penetapan hukum agama juga dalam hal perilaku dan gaya hidup. Semangat pemurnian ajaran (purification) dan kembali ke gaya hidup salaf adalah semangat utama yang mengalir dalam konsep dan ajaran salafiyyun. Purifikasi dan pendidikan memang merupakan pendekatan praktis (practical approach) yang dilakukan oleh gerakan salafi untuk menyebarkan ajaran yang sesuai manhaj mereka. Purifikasi yang dimaksud, menurut Jacob Olidort, adalah memurnikan akidah (Islam) dari keyakinan palsu, merusak, dan bentuk kemusyrikan apa pun yang masuk, dan memurnikan sunah dari semua hal asing memasukinya. ${ }^{25}$

\section{Sistem Pendidikan Gerakan Salafi di Kota Metro}

Bagi para anggota gerakan salafi, pendidikan anak harus di awali oleh orang tuanya dan oleh karena itu mereka harus di tanamkan faham syariat yang di yakini oleh mereka. Anak-anak di kalangan gerakan salafi di didik secara intens sejak dini. Dimulai dari cara berpakaian yang sudah di ajarkan bagaimana berpakaian yang sesuai syariat yang diyakini oleh orang tua yang Salafi. Di Desa Purwosari Kota Metro, anak laki-laki dari orang tua yang salafi banyak yang menggunakan kopiah, baju koko dan celana panjang di atas mata kaki atau yang sering di sebut "cingkrang". Pakaian seperti ini tidak hanya dikenakan pada saat mereka mengaji atau ikut orang tua mereka sholat berjama'ah di masjid, akan tetapi juga ketika mereka bermain dengan teman-temannya.

Terkait pendidikan formal, terdapat pandangan yang cukup berbeda dari kalangan salafi dengan di luar salafi. Misalnya, anak usia PAUD atau kober (kelompok bermain) di perbolehkan untuk di sekolahkan di sekolah manapun, termasuk sekolah umum yang menggabungkan peserta didik laki-laki dan perempuan di

25 Jacob Olidort, "The Politics of "Quietest" Salafism", The Brookings Project on U.S. Relations with the Islamic World. Analysis Paper No. 18, February 2015, h.15. 
dalam satu ruangan kelas. Untuk tingkat lanjutan seperti SMP dan SMA, beberapa orang tua salafi bahkan tidak mengirimkan anakanak mereka ke SMP atau SMA. Bagi mereka, yang terpenting adalah ilmu-ilmu agama. Oleh karena itu banyak anak-anak Salafi tidak memiliki ijazah SMP dan SMA. Menurut mereka, asalkan sudah bisa membaca, menulis dan berhitung, maka sudah cukup sebagai bekal anak-anak mereka. ${ }^{26} \mathrm{Hal}$ ini terlihat dari beberapa keluarga Salafi yang mengirimkan anak-anaknya ke pesantren salafi tanpa menyekolahkan mereka di sekolah-sekolah umum.

Kemudian apabila anak-anak sudah menginjak usia sekolah dasar, para orang tua salafi akan mengirimkan anak-anak mereka kepada pendidikan yang berideologi salafi juga, meskipun terkadang jaraknya jauh dari kediaman mereka. Mereka yakin untuk memilih lembaga pendidikan yang berideologi salafi karena mereka tidak perlu khawatir untuk mengawasi anak-anak mereka.

"di sekolah ini, anak-anak usia SD sudah ditempatkan secara terpisah antara laki-laki dan perempuan karena di usia ini, anakanak mulai memahami apa itu cantik dan apa itu ganteng. Jadi, mereka harus dipisah sejak dini" 27

Para guru yang mengajar juga harus disesuaikan dengan jenis kelamin peserta didik. Maksudnya, di kelas yang terdiri dari para santri putra, maka guru-gurunya juga harus laki-laki, dan begitu pula sebaliknya. Untuk para orang tua Salafi di Kota Metro, sebagian besar mengirimkan anak mereka di lembaga pendidikan Salafi di Desa Nunggal Rejo, Punggur, Lampung Tengah dengan jarak tempuh sekitar 30 menit-1 jam dengan kendaraan bermotor.

26 Wawancara dengan IV, di kediamannya di Kelurahan Purwosari Kec. Metro Utara Kota Metro, pukul 16.00 WIB

27 Wawancara dengan IV, di kediamannya di Kelurahan Purwosari Kec. Metro Utara Kota Metro, pukul 16.00 WIB 


\section{a. Pesantren Manhaj Salafi}

Salah satu pesantren ber-manhaj salafi di Kota Metro adalah Ma'had Ittibaus Salaf (Masjid Al-Abror) yang berlokasi di Jl. Seriti V, Kelurahan Purwoasri, Metro Utara, Kota Metro, Lampung. Menurut data yang diambil dari Pangkalan Data Pondok Pesentren (PDPP) Kemenrian Agama, pesantren ini memiliki jumlah santri 150 orang dan guru berjumlah 22 orang. ${ }^{28}$

Ma'had Ittibaus Salaf termasuk pesantren yang dikembangkan oleh kelompok salafi puris yang kooperatif. Pesantren ini juga tidak termasuk ke manhaj salafi yang rejeksionis karena mereka tidak hanya mengembangkan ilmu pengetahuan Islam tetapi juga pengetahuan umum dan juga mengikuti kurikulum nasional. Menurut pengurus ma'had juga, terdapat beberapa program di pesantren ini yang diperuntukkan bagi masyarakat umum atau yang mereka namai sebagai ta'lim umum. Berikut ini adalah jadwal kajian bagi masyarakat umum di pesantren ini.

Tabel 1.

Jadwal Ta'lim Umum di Ma'had Ittibaus Salaf Kota Metro

\begin{tabular}{|l|l|l|l|l|}
\hline \multicolumn{1}{|c|}{ Materi } & Waktu & \multicolumn{1}{c|}{ Pengajar } & \multicolumn{1}{c|}{ Peserta } & \multicolumn{1}{c|}{ Lokasi } \\
\hline $\begin{array}{l}\text { Hadits: } \\
\text { Riyadus- } \\
\text { sholihin }\end{array}$ & $\begin{array}{l}\text { Hari } \\
\text { Ahad } \\
\text { Ba'da } \\
\text { Magrib }\end{array}$ & $\begin{array}{l}\text { Al Ustadz Adi } \\
\text { Abdullah } \\
\text { (Lulusan Ma'had } \\
\text { Darul Hadits } \\
\text { Dammaj, Yaman) }\end{array}$ & $\begin{array}{l}\text { Umum/Laki- } \\
\text { laki/Ikhwan/ } \\
\text { Perempuan/A } \\
\text { khwat }\end{array}$ & $\begin{array}{l}\text { Ma'had } \\
\text { Ittiba'ussalaf, } \\
\text { Desa Badran, } \\
\text { Kel } \\
\text { Purwoasri, } \\
\text { Kota Metro }\end{array}$ \\
\hline $\begin{array}{l}\text { Aqidah: } \\
\text { Fadlul } \\
\text { Islam }\end{array}$ & $\begin{array}{l}\text { Hari } \\
\text { Senin } \\
\text { Ba'da } \\
\text { Magrib }\end{array}$ & $\begin{array}{l}\text { Al Ustadz Harits } \\
\text { (Lulusan Ma'had } \\
\text { Darul Hadits } \\
\text { Dammaj, Yaman) }\end{array}$ & $\begin{array}{l}\text { Umum/Laki- } \\
\text { laki/Ikhwan/ } \\
\text { Perempuan/ } \\
\text { Akhwat }\end{array}$ & $\begin{array}{l}\text { Ma'had } \\
\text { Ittiba'ussalaf, } \\
\text { Desa Badran, } \\
\text { Kel } \\
\text { Purwoasri, }\end{array}$ \\
\hline $\begin{array}{l}\text { Aqidah: } \\
\text { Syarhus- } \\
\text { sunnah }\end{array}$ & $\begin{array}{l}\text { Hari } \\
\text { Selasa } \\
\text { Ba'da } \\
\text { Magrib }\end{array}$ & $\begin{array}{l}\text { Al Ustadz Adi } \\
\text { Abdullah } \\
\text { (Lulusan Ma'had } \\
\text { Darul Hadits } \\
\text { Dammaj, Yaman) }\end{array}$ & $\begin{array}{l}\text { Umum/Laki- } \\
\text { laki/Ikhwan/ } \\
\text { Perempuan/A } \\
\text { khwat }\end{array}$ & $\begin{array}{l}\text { Ma'had } \\
\text { Ittiba'ussalaf, } \\
\text { Desa Badran, } \\
\text { Kel } \\
\text { Purwoasri, }\end{array}$ \\
\hline
\end{tabular}

28 Diakses dari http://pbsb.ditpdpontren.kemenag.go.id/pdpp/profil/23574 pada tanggal 9 September 2018. 


\begin{tabular}{|l|l|l|l|l|}
\hline & & & & Kota Metro \\
\hline $\begin{array}{l}\text { Fiqh: } \\
\text { Bulughul } \\
\text { Marom }\end{array}$ & $\begin{array}{l}\text { Hari Rabu } \\
\text { Ba'da } \\
\text { Magrib }\end{array}$ & $\begin{array}{l}\text { Al Ustadz Harits } \\
\text { (Lulusan Ma'had } \\
\text { Darul Hadits } \\
\text { Dammaj, Yaman) }\end{array}$ & $\begin{array}{l}\text { Umum/Laki- } \\
\text { laki/Ikhwan/ } \\
\text { Perempuan/A } \\
\text { khwat }\end{array}$ & $\begin{array}{l}\text { Ma'had } \\
\text { Ittiba'ussalaf, } \\
\text { Desa Badran, } \\
\text { Kel } \\
\text { Purwoasri, } \\
\text { Kota Metro }\end{array}$ \\
\hline $\begin{array}{l}\text { Hadits: } \\
\text { Arbain } \\
\text { Nawawi }\end{array}$ & $\begin{array}{l}\text { Hari } \\
\text { Kamis }\end{array}$ & $\begin{array}{l}\text { Al Ustadz Harits } \\
\text { (Lulusan Ma'had } \\
\text { Darul Hadits } \\
\text { Dammaj, Yaman) }\end{array}$ & $\begin{array}{l}\text { Umum/Laki- } \\
\text { laki/Ikhwan/ } \\
\text { Perempuan/A } \\
\text { khwat }\end{array}$ & $\begin{array}{l}\text { Ma'had } \\
\text { Ittiba'ussalaf, } \\
\text { Desa Badran, } \\
\text { Kel } \\
\text { Purwoasri, }\end{array}$ \\
\hline $\begin{array}{l}\text { Tafsir: } \\
\text { Tafsir } \\
\text { Assa'di }\end{array}$ & $\begin{array}{l}\text { Hari } \\
\text { Jum'at } \\
\text { Ba'da } \\
\text { Magrib }\end{array}$ & $\begin{array}{l}\text { Al Ustadz Adi } \\
\text { Abdullah } \\
\text { (Lulusan Ma'had } \\
\text { Darul Hadits } \\
\text { Dammaj, Yaman) }\end{array}$ & $\begin{array}{l}\text { Umum/Laki- } \\
\text { laki/lkhwan/ } \\
\text { Perempuan/A } \\
\text { khwat }\end{array}$ & $\begin{array}{l}\text { Ma'had } \\
\text { Ittiba'ussalaf, } \\
\text { Desa Badran, } \\
\text { Kel } \\
\text { Purwoasri, }\end{array}$ \\
& & Damata & & Kota Metro \\
\hline
\end{tabular}

Namun, meski terbilang sebagai kelompok salafi yang inklusif dan kooperatif, seringkali kecenderungan bersikap kaku dan tekstualis dalam memahami ayat-ayat al-Quran dan hadits-hadits nabi, membuat mereka jatuh pada fanatisme pemahaman buta. Apa yang di pahami oleh yang satu secara tekstual, ketika berbeda sedikit saja dengan yang lain, akan menimbulkan friksi yang sangat tajam, meskipun itu pada hal-hal yang dalam wilayah agama termasuk furu' (cabang) saja, bukan wilayah yang fundamental.

Hal-hal tersebut membuat jamaah Salafiyyun cenderung gampang terpecah dalam berbagai kelompok atau golongan. Muncul adanya truth claim, yakni kelompok yang satu merasa lebih dan paling salaf dibandingkan dengan kelompok yang lainnya. Demikian pula sebaliknya, kelompok yang dituduh kurang salaf, mengklaim kelompoknya yang paling salaf sementara kelompok lain yang menuduh justru yang paling tidak sesuai dengan salaf. Paling memenuhi kriteria salaf dan kurang salaf atau bahkan sudah tidak sesuai dengan salaf, pada akhirnya menjadi 
klaim atau menjadi labelling bagi dinamika dalam kelompok jamaah Salafiyyun.

Fenomena merasa paling benar ini kemudian menimbulkan perpecahan. Hal ini senada dengan apa yang disampaikan oleh Karwadi bahwa agama mengandung potensi pemecah muncul ketika masing-masing pemeluk agama mengklaim ajaran agamanya paling benar dan agama orang lain salah. Klaim kebenaran (truth claim) masing-masing pemeluk agama berpotensi melahirkan sikap tertutup (exlusive). ${ }^{29}$ Selanjutnya eklusifitas pemahaman agama tersebut dapat menjadi lahan subur bagi perkembangan radikalisme. Sebab, salah satu faktor mendasar yang menyulut api radikalisme, menurut Stark, adalah ketika agama difahami dan diajarkan dengan corak ekslusifpartikularistik. ${ }^{30}$

Di Kota Metro, sebagaimana dijelaskan Mukhtar Hadi, bahwa ada beberapa tempat yang merupakan kantong jamaah salaf, diantaranya adalah komunitas salaf yang berada di Hadimulyo Timur yang di pelopori oleh mantan aktivis Muhammadiyah, Ustadz Mahdi. Jamaah Hadimulyo Timur ini memiliki afiliasi dengan beberapa jamaah salafi di Adirejo, Pekalongan Lampung Timur dan juga dengan jamaah salafi di wilayah Punggur, Lampung Tengah. Sementara Ittibaussalaf adalah varian salafi yang berbeda dengan jamaah salafi Hadimulyo Timur dan Punggur tersebut. Jamaah Ittibaussalaf kebanyakan adalah alumni Lasykar Jihad Alussunnah wal Jamaah yang pernah dibentuk oleh tokoh salafi Ja'far Umar Thalib. ${ }^{31}$

${ }^{29}$ Karwadi, “Deradikalisasi Pemahaman Ajaran Islam”, Al-Tahrir, Vol. 14, No. 1 Mei 2014: h. 139-156.

30 Radney Stark, One True God, Resiko Sejarah Bertuhan Satu, terj. M. Sadat Ismail (Yogyakarta: Penerbit Qalam dan Nizam Press, 2003), h. 171.

31 Mukhtar Hadi, "Fenomena Kelompok Keagamaan Baru (Heresy) Dalam Islam (Studi Terhadap Jama'ah Ittiba' al-Salaf di Purwoasri Metro Utara)" Jurnal RI'AYAH, Vol. 02, No. 02 Juli-Desember 2017, h. 1-19. 


\section{b. Proses Pembelajaran di Pesantren Manhaj Salafi}

Ma'had Ittibaus Salaf mengembangkan program-program seperti program tahfidh al-Qur'an (menghapal al-Qur'an), program tadrib al-duat (pelatihan mengajar), dan program tarbiyatun nisa' (pendidikan wanita). Pesantren ini di dekikasikan untuk pengajaran agama Islam. Pesantren salafi memang tidak terlalu berbeda dengan pesantren-pesantren pada umumnya, pesantren salafi sebagai tempat pendidikan agama Islam, lebih khusus sebagai pusat pengembangan model keberagamaan ber-manhaj salafi.

Pengajaran manhaj salafi di pesantren, sebagaimana di uraikan Irham, telah dimulai sejak dini. Misalnya di tingkat TK, model penerapannya dengan mengajarkan doktrin salafi yang paling dasar. Misalnya, para peserta didiknya diminta untuk mampu mengingat macam-macam ibadah yang penting yang berdasar atas Hadits Nabi. Anak-anak juga tidak diperbolehkan untuk menggambar makhluk hidup (seperti manusia dan hewan) dan menyanyikan lagu. Seluruh sistem pendidikan Salafi mewajibkan adanya pemisahan perempuan dari laki-laki dengan kelas yang berbeda. Sementara itu, guru yang mengajar anak-anak itu adalah seorang wanita yang bercadar namun ketika dalam kelas cadarnya dibuka. ${ }^{32}$ Hal ini juga terdapat di ma'had Ittibaus Salaf.

Kemudian, siswa yang berusia belasan ke atas atau siswa dewasa terlebih yang senior di sediakan jenis program pelatihan pengajaran di peruntukkan. Program ini bertujuan untuk membuat siswa mampu mengajarkan atau menyebarkan pengetahuan yang dimiliki kepada orang lain. Program ini tidak terbatas pada kurikulum, waktu atau tempat tertentu. Karena semua santri tinggal di pesantren, sehingga menjadi fleksibel. Kurikulum tergantung dan ditentukan dari guru yang bertanggung

32 Irham, "Pesantren Manhaj Salafi: Pendidikan Isalm Model Baru di Indonesia” Ulul Albab, vol. 17, No.1 2016, h.9. 
jawab. Biasanya dalam pengajaran ini satu guru memberikan satu sampai tiga pembahasan dengan menggunakan satu pedoman buku. Metode yang digunakan adalah Mulazama, yaitu guru berceramah atau menjelaskan pembahasan dalam buku pedoman sementara itu santri berkumpul dan mendengarkan. Metode ini sama dengan yang diterapkan pesantren tradisional yang biasa disebut dengan bandongan/wetonan dimana santri mendengarkan uraian-uraian kyai terhadap penerjemahan atau penjelasan kitab yang dibaca. ${ }^{3}$

\section{Niqab dan Posisi Perempuan dalam Pendidikan Salafi}

a. Cadar Muslimah Salafi

Cadar (niqab) sudah menjadi ciri khas perempuan salafi. Selain itu, berdasarkan paparan M, jilbab untuk perempuan Salafi terbebas dari warna dan model yang menarik perhatian karena tujuannya adalah untuk menutupi kecantikan dan bukan sebaliknya. Mereka meyakini bahwa cara berpakaian seperti itulah yang sesuai dengan agama. ${ }^{34}$ Mengenai cara berpakaian, salafi berlandaskan QS. Al Ahzab ayat 53 yang menerangkan bahwa isteri-isteri nabi menggunakan hijab dari balik tabir. Jika ada seseorang yang hendak berkunjung ke rumah Nabi, para istri Nabi menggunakan hijabnya yang berada di balik tabir. Mereka menafsirkan "mengulurkan jilbab ke seluruh tubuh" yang tercantum di dalam QS. Al Ahzab ayat 59 sebagai menutupi wajah dan kedua telapak tangan.

Berdasarkan penuturan dari informan, mereka menggunakan cadar untuk menjaga kesucian seperti istri nabi, dan mereka memahami bahwa pada dasarnya menggunakan cadar tidaklah wajib atau sunnah, namun tujuan mereka adalah untuk menjalankan sunnah yang dilakukan oleh nabi dan istri-

33 Zamakhsyari Dhofier, Tradisi Pesantren Studi Pandangan Hidup Kyai Dan Visinya Mengenai Masa Depan Indonesia. Cet. ke-8. Jakarta: LP3ES, 2011, h. 79-99. 2017.

34 Hasil observasi awal dan wawancara dengan M pada tanggal 16 Februari 
istrinya. ${ }^{35}$ Mereka sudah diwajibkan untuk mengenakan cadar sejak mereka baligh. Banyak juga anak-anak perempuan yang belum baligh; hal ini untuk mendidik mereka sejak dini dan membiasakan mengikuti kewajiban bercadar tersebut. Saat ini fenomena wanita bercadar semakin meluas, meskipun awalnya mereka sama sekali tidak tergabung dalam kelompok salafi. Namun pada akhirnya mereka semakin "fall in love" kepada Islam salafi ini karena mereka melihat Islam salafi lebih autentik dari pada Islam yang di tampilkan oleh ormas Islam lain. 36

Di kehidupan sehari-hari, para perempuan salafi biasanya berada di rumah untuk mengurusi rumah tangga dan jarang keluar kecuali ada keperluan, itupun harus di sertai dengan suaminya atau muhrim-nya. Kaum perempuan, dari ibu-ibu hingga anak-anak menggunakan pakaian warna gelap ukuran lebar, tertutup rapat dan bercadar. Sementara kaum laki-laki dewasa juga anak-anak menggunakan pakaian gamis dengan celana atau sarung hingga sebatas tengah betis kaki. Kadangkadang kaum laki-laki menambah surban atau peci kain sebagai pelengkap tambahan dalam berpakaian. Ini adalah pakaian wajib yang digunakan baik di area kompleks maupun keluar kompleks. Cara berpakain seperti ini dipahami dan diyakini sebagai pakaian sunnah, yang juga dipakai oleh para salafus salih. ${ }^{37}$

Saat memutuskan untuk bercadar, perempuan salafi mendapatkan pengalaman yang berbeda terkait hubungan mereka dengan lingkungan sekitar seperti teman atau kerabat. Sebagian besar akan merasa ada gap atau jarak antara mereka

35 Eveline Ramadhini, "Jilbab sebagai Representasi Simbolik Mahasiswi Muslim di Universitas Indonesia", MASYARAKAT: Jurnal Sosiologi, Vol. 22, No. 1, Januari 2017: h. 81-103.

${ }^{36}$ Eva F Nisa, "Embodied Faith: Agency and Obedience among Face-veiled University Students in Indonesia", The Asia Pacific Journal of Anthropology..., h.131.

37 Mukhtar Hadi, "Fenomena Kelompok Keagamaan Baru (Heresy) Dalam Islam (Studi Terhadap Jama'ah Ittiba’ al-Salaf di Purwoasri Metro Utara)..., h. 15. 
dan teman-teman mereka. Bahkan, dengan keluarga pun mereka menjadi merasa lebih jauh karena berbeda pandangan. Seperti halnya yang diungkapkan oleh NN,

"Hubungan dengan kawan lama memang agak ada jarak. Bahkan dengan keluarga juga demikian. Seperti keluarga adik-adek rasanya menjadi lebih jauh. Mungkin karena berbeda faham". ${ }^{38}$

Ketetapan pemakaian jilbab manhaj Salafi tersebut menjadi ciri khas di antara jilbab cadar kelompok lain dan sekian banyak varian model jilbab yang ada. Mereka berprinsip semakin tertutup semakin baik. Pada titik selanjutnya muncul penasaran penulis terkait pemakaian jilbab di kalangan perempuan Salafi seputar pemaknaan.

\section{b. Tarbiyah Al-Nisa: Program Pendidikan Wanita Salafi}

Kelompok Salafi memiliki program tersendiri untuk para wanita. Program pendidikan wanita (tarbiyah al-nisa') tersebut merupakan kegiatan yang bertujuan untuk mepersiapkan siswa perempuan untuk menjadi istri yang dapat mendukung suaminya nanti dalam mendukung dan mengembangkan salafisme. Materi yang esensial sebagai bahan kajian adalah hubungan antara suami dan istri, secara khusus merujuk pada kitab Syaikh Muqbil yang berjudul Nasiha lil al Nisa'. Para peserta didik perempuan di ajar oleh para guru wanita dan tidak dicampur dengan peserta didik laki-laki. Konsep pemisahan laki-laki dan perempuan di dalam pendidikan (single-sex education) memang merupakan salah satu ajaran yang urgen di dalam gerakan Salafi.

Para anak perempuan yang belum baligh juga sudah diajarkan untuk selalu menggunakan pakaian syar'i yang umumnya berupa baju gamis dan jilbab besar. Sebelum mereka baligh, anak perempuan belum diwajibkan untuk

38 Wawancara dengan NN, di kediamannya di desa Banjarsari Metro Utara pada tanggal 12 Oktober 2017 pada pukul 14.00 WIB. 
mengenakan cadar karena belum wajib untuk menutup aurat. Namun, setelah si anak perempuan Salafi ini sudah baligh, meskipun mereka masih di bangku SD, mereka diharuskan mengenakan cadar (niqab) untuk menutup wajahnya. ${ }^{39} \mathrm{Jadi}$, tidak mengherankan apabila di lingkungan yang kelompok salafi ini, akan banyak terlihat anak laki-laki sudah mengenakan baju koko, celana di atas mata kaki dan kopiah saat mereka bermain. Begitu juga, banyak terlihat anak kecil yang belum baligh sudah mengenakan jilbab besar saat mereka melakukan kegiatan sehari-harinya, bahkan sudah ada yang bercadar dan berpakaian dengan warna gelap.

Selain itu, para perempuan salafi juga diajari keterampilan lain seperti memasak dan jahit-menjahit. Untuk mendapatkan pemahaman atau isu-isu baru tentang keperempuanan, pesantren menyediakan majalah, misalnya majalah assunnah yang secara khusus menyediakan pembahasan tentang keperempuanan, seperti adanya rubrik syakhsiah (personality), baytuna (our home), majalah Fatawa yang di terbitkan oleh Bin Baz Center yang menyediakan rubrik keluarga sakinah (harmonious family), majalah al-Mawaddah yang diterbitkan pesantren al-Furqon, dan masih banyak lainnya. Penjelasan bentuk pendidikan mannhaj Salafi ini tidak jauh berbeda seperti yang disebutkan dalam disertasi Noorhaidi, misalnya tentang penjelasan jaringan pesantren Ihyaus Sunnah Degolan Kaliurang Yogyakarta. ${ }^{40}$ Jadi, dapat kita pahami bahwa meskipun terkesan tertutup dan dikenal sebagai perempuan yang sangat "rumahan" dan bertugas hanya disekitar tugas sebagai istri dan ibu rumah tangga, ternyata para perempuan Salafi tetap diberikan perhatian yang besar. Hal ini dapat

39 Wawancara dengan IV, di kediamannya di kelurahan Purwosari Kec. Metro Utara Kota Metro, pukul 16.00 WIB

40 Noorhaidi, "Laskar Jihad Islam, Militancy and The Quest for Identity in Post-New Order Indonesia." Ph.D. Dissertation. Utrecht university, h. 84-89. 
dilihat dari berbagai program yang disediakan untuk kaum hawa ini.

Selain itu, terdapat juga majelis khusus perempuan salafi. Pada acara pengajian-pengajian tersebut, perempuan salafi boleh mengajak siapa saja sesama perempuan. Pada pengajian tersebut orang yang diajak tidak harus memakai cadar juga. Di pesantren salafi setiap 3 bulan sekali ada pengajian akbar yang diisi oleh ustadz dari Jawa. Pada acara terebut orang salafi dari berbagai daerah hadir dengan saudara maupun kenalan baik yang sudah menggunakan cadar maupun yang belum. Dari acara tersebut beberapa keluarga yang belum mengikuti manhaj Salafi biasanya terus mengikuti. Dakwah yang khusus bagi perempuan salafi adalah apabila suaminya merokok harus membuatnya berhenti merokok secara perlahan. Karena merokok di larang bagi orang salafi.

Apabila perempuan salafi memiliki pekerjaan misalnya menjadi karyawan di suatu perusahaan atau menjadi tenaga pendidik di suatu sekolah, maka untuk berangkat ke tempat kerja, si peremuan harus didampingi oleh mahram atau suami bagi yang sudah menikah. Menurut salah satu informan, SS, kewajiban untuk ditemani oleh suami tidak harus disemua kondisi. Meskipun tidak dilakukan oleh semua perempuan salafi, ia dan suami memiliki strategi tersendiri untuk tetap dapat berinteraksi dengan lingkungan sekitar sekaligus tetap berpijak kepada syariat Islam yang selalu mereka yakini. Ia dan suaminya memiliki sejenis perjanjian kontrak yang salah satu isinya adalah apabila ia bepergian ke luar Kota Metro, maka tidak boleh ditemani oleh selain suami. Namun jika bepergian ke daerah yang masih di area Kota Metro, ia dapat ditemani oleh teman, saudara atau rekan kerja, yang penting mereka perempuan. ${ }^{41}$

41 Wawancara dengan Susi, di dalam ruang guru PAUD Al-Mukhsin, Purwosari, Kota Metro, pada tanggal 16 Oktober 2017 pukul 11.00 WIB. 
Dari uraian diatas dapat disimpulkan bahwa pola komunikasi para perempuan salafi tidak sepenuhnya tertutup. Mereka tetap di perbolehkan bergaul dengan orang di luar golongan salafi, hanya saja mereka tertutup untuk bergaul dengan lawan jenis secara terbuka. Jadi yang membedakan adalah perempuan salafi harus didampingi oleh mahram-nya jika akan bepergian atau akan berinteraksi dengan laki-laki yang bukan mahram-nya.

\section{Kesimpulan}

Perkembangan gerakan salafi di Kota Metro dipengaruhi oleh beberapa faktor dan salah satu faktor terkuat adalah ranah pendidikan melalui pesantren. Pesantren, atau yang mereka sebut sebagai ma'had, ini menjadi pusat kajian pendidikan Islam dan menjadi wahana utama untuk penanaman manhaj mereka, yakni pemurnian agama dari praktik-praktik keagamaan (purification of religion) yang tidak dicontohkan oleh Nabi Muhammad SAW.

Sementara itu, di bidang pendidikan, para perempuan salafi tidak diperkenankan menimba ilmu selain di lembaga pendidikan yang ber-manhaj salafi karena mereka, di khawatirkan, akan memiliki pandangan yang berbeda. Untuk memberikan kesempatan yang luas bagi para pemudi salafi untuk mengenyam pendidikan agama Islam, pesantren Ittibaus Salaf menjalankan program tarbiyah al-nisa. Majelis-majelis khusus perempuan salafi, yang juga boleh dihadiri oleh perempuan non-salafi, juga didirikan untuk meningkatkan wawasan keilmuan dan juga sebagai sarana bersosialisasi baik dengan sesama muslimah salafi maupun dengan perempuan lain pada umumnya.[]

\section{Daftar Pustaka}

Afifah, Nurul, "Problematika Pendidikan di Indonesia (Telaah dari Aspek pembelajaran)”, Elementary: Jurnal Ilmiah Pendidikan Dasar 1, no. 1, 2015.

Azra, Azyumardi, Pendidikan Islam Tradisi Dan Modernisasi Di Tengah Tantangan Millenium III. Jakarta: Kencana, 2012. 
Byman, d., Variations within the Salafi Movement: Three Main Themes in Salafism. 2014. Diakses dari https://repository.library. georgetown.edu/bitstream/handle/10822/1041681/GUIX501-01-14-W4-S12.pdf?sequence=1 pada 2 November 2018.

Dhofier, Zamakhsyari, Tradisi Pesantren Studi Pandangan Hidup Kyai Dan Visinya Mengenai Masa Depan Indonesia, Cet. ke-8. Jakarta: LP3ES. 2011.

Duderija, Adis, Constructing the Religious Self and the Other: NeoTraditional Salafi Manhaj. Islam and Christian-Muslim Relations 21(1), 2010.

Hadi, Mukhtar, Fenomena Kelompok Keagamaan Baru (Heresy) Dalam Islam (Studi Terhadap Jama'ah Ittiba' al-Salaf di Purwoasri Metro Utara), Jurnal RI'AYAH, Vol. 02, No. 02 Juli-Desember 2017.

Hasan, Noorhaidi. "Laskar Jihad Islam, Militancy and The Quest for Identity in Post-New Order Indonesia." Ph.D. Dissertation. Utrecht university, 2005.

Hegghammer, Thomas, Jihadi Salafis or Revolutionaries: On Religion and Politics in the Study of Islamist Militancy", dalam R Meijer (ed), Global Salafism: Islam's New Religious Movement London/New York: Hurst/Columbia University Press, 2009.

http://pbsb.ditpdpontren.kemenag.go.id/pdpp/profil/23574diakses pada tanggal 9 September 2018.

International Crisis Group, Indonesia: Industri Penerbitan Jemaah Islamiyah, Asia Report No. 142, 24 Pebruari 2008.

Irham, "Pesantren Manhaj Salafi: Pendidikan Isalm Model Baru di Indonesia" Ulul Albab, volume 17, No.1, 2016.

Karwadi, “Deradikalisasi Pemahaman Ajaran Islam”, Al-Tahrir, Vol. 14, No. 1 Mei 2014. 
Kovacs, A., Saudi Arabia exporting Salafi education and radicalizing Indonesia's Muslims (GIGA Focus International Edition, 7). Hamburg: GIGA German Institute of Global and Area Studies Leibniz-Institut für Globale und Regionale Studien. Diakses dari https://nbn-resolving.org/urn:nbn:de:0168-ssoar402325 .

Madkur, A \& Albantani, A., M, Instilling Islamic Values in Foreign Language Teaching: An Indonesian Context, The International Conference on Education in Muslim Society. Advances in Social Science, Education and Humanities Research, vol. 115, Atlantis Press, 2018.

Nisa, F., E. "Embodied Faith: Agency and Obedience among Face-veiled University Students in Indonesia", The Asia Pacific Journal of Anthropology, vol. 13, No. 4, August 2012.

Olidort, Jacob, The Politics of "Quietest" Salafism, The Brookings Project on U.S. Relations with the Islamic World. Analysis Paper No. 18, February 2015.

Olsson, Susanne, "Swedish Puritan Salafism: A Hijra Within." Comparative Islamic Studies 8 (1-2), 2012.

Prima, A., R., M., "Mediatisasi pada Aktivitas Dakwah Perempuan Salafi", RI'AYAH, Vol. 01, No. 02 Juli-Desember 2016.

Rahmat, I., M. Arus Baru Islam Radikal, Transmisi Revitalisme Islam Timur Tengah di Indonesia, Jakarta: PT. Erlangga, 2005.

Ramadhini, Eveline, Jilbab sebagai Representasi Simbolik Mahasiswi Muslim di Universitas Indonesia, MASYARAKAT: Jurnal Sosiologi, Vol. 22, No. 1, Januari 2017.

Solihin, Imam, "Madrasah dan Pertumbuhan Keilmuan Dunia Islam: Sebuah Kajian Sosio-Historis". Elementary: Jurnal Ilmiah Pendidikan Dasar, [S.l.], v. 4, n. 1, june 2018. 
Stark, Radney, One True God, Resiko Sejarah Bertuhan Satu, terj. M. Sadat Ismail, Yogyakarta: Penerbit Qalam dan Nizam Press, 2003.

Stiawan, Kelik dan Tohirin, M., Format Pendidikan Pondok Pesantren Salafi dalam Arus Perubahan Sosial di Kota Magelang, Jurnal CAKRAWALA, Vol. X, No. 2, Desember 2015.

W. Ende, Salafiyya, Encyclopedia of Islam, Vol. 8, Leiden: Brill, 1995.

Wahid, Din, Nurturing The Salafy Manhaj: A Study of Salafi Pesantrens in Contemporary." Disertasi Utrecht University, 2014.

Wiktorowicz, Quintan. "Anatomy of the Salafi Movement", Studies in Conflict \& Terrorism, 29: 3, 2006.

Wawancara:

Wawancara dengan IV, di kediamannya di kelurahan Purwosari Kec. Metro Utara Kota Metro, pukul 16.00 WIB

Wawancara dengan NN, di kediamannya di desa Banjarsari Metro Utara pada tanggal 12 Oktober 2017 pada pukul 14.00 WIB.

Wawancara dengan Ss, di dalam ruang guru PAUD Al-Mukhsin, Purwosari, Kota Metro, pada tanggal 16 Oktober 2017 pukul 11.00 WIB. 